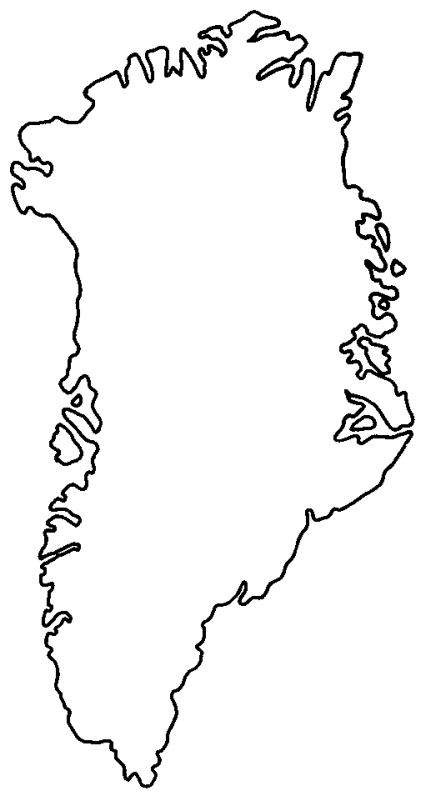

\title{
Tetinia (Trilobita) from the late Silurian of western North Greenland
}

\author{
Philip D. Lane, Poul-Henrik Larsen and \\ Jan C. Escher
}

\begin{abstract}
A late Silurian trilobite, Tetinia sp., is described from the Wulff Land Formation of the Peary Land Group in western North Greenland. The record is the first in Greenland of a genus otherwise only known from Czechoslovakia, Gotland, Podolia and Britain.

P. D. L., Department of Geology, University of Keele, Keele, Staffordshire ST5 5BG, U.K.

P.-H. L. \& J. C. E., Grønlands Geologiske Undersøgelse, $\emptyset$ ster Voldgade 10, DK-1350 København K, Danmark.
\end{abstract}

Among an extensive collection of graptolites recovered by J. C. Escher and P.-H. Larsen during fieldwork (1984-1985) in the Peary Land Group in western North Greenland (Hurst \& Surlyk, 1982; Larsen \& Escher, 1985), two small trilobite elements - a cranidium and pygidium - were found on the same small slab. The slab was from a section in the Wulff Land Formation in Permin Land (fig. 1). Both elements are proetid in character and of a similar size, so that although they probably do not belong to the same individual (the pygidium is rather too small to belong to the cranidium) they do probably belong to the same species.

The trilobite, considered below to belong to Tetinia sp. (fig. 2) occurred in a $25 \mathrm{~m}$ black shale interval together with the graptolite Bohemograptus bohemicus, indicating a Ludlow (late Silurian) age. Saetograptus fritschi linearis was collected just above this interval, probably indicating a basal Ludfordian (late Ludlow) age.

\section{Systematic description}

Family Proetidae Salter, 1864

Subfamily Warburgellinae Owens, 1973

Genus Tetinia Chlupáč, 1971

Type species. By original designation of Chlupáč (1971), Prantlia minuta Přibyl \& Vaněk, 1962 from the Přidolí of Czechoslovakia; the type species also occurs in the top of the Přidolí in Podolia, U.S.S.R. (R. M. Owens, personal communication, 1986).

Diagnosis. See Šnajdr (1980, p. 176).

Figured material. MGUH 17.449 and MGUH 17.450 from GGU sample 319211. 


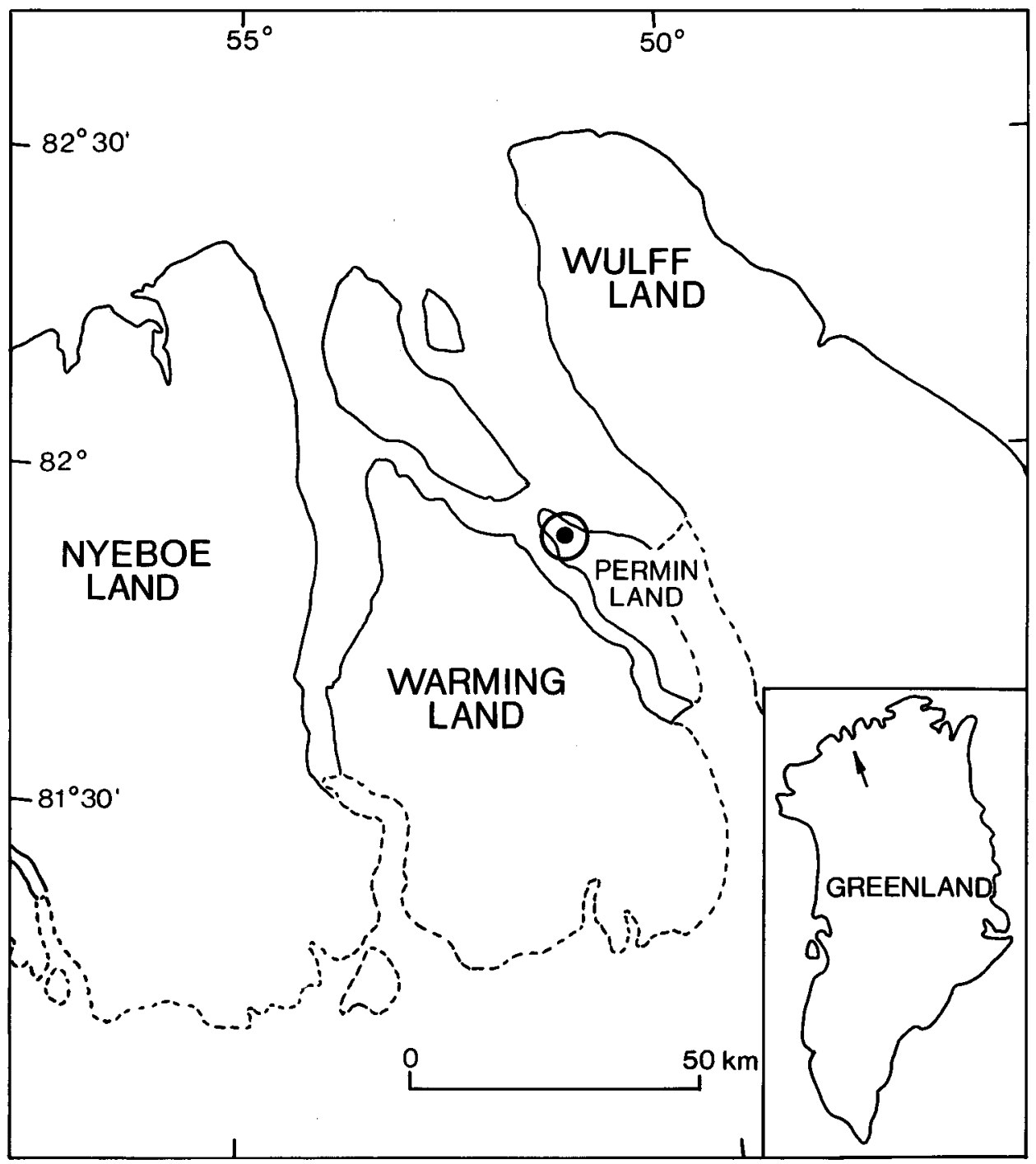

Fig. 1. Map showing sample locality for the late Silurian trilobite Tetinia sp. in western North Greenland.

\section{Tetinia sp.}

Fig. 2

Discussion. The genus is known only from two described species - the type species and $T$. ludlowensis (Alberti, 1967; see Owens 1973, p. 72, pl. 14, figs 14-18, pl. 15, figs 1, 2) from the Ludfordian (late Ludlow) of the Welsh Borderland, U.K. and at a similar horizon in Gotland, Sweden. 
Fig. 2. Tetinia sp., Wulff Land Formation, Permin Land, GGU sample 319211. latex impressions, $\times$ 4. A, MGUH 17.449 , cranidium. B, MGUH 17.450, pygidium.

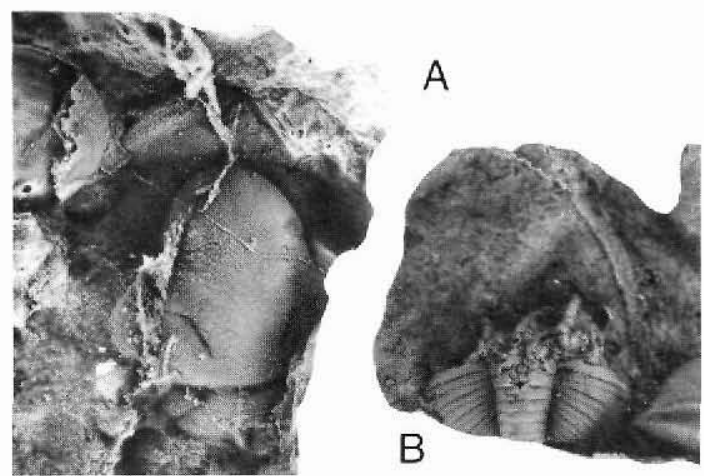

The small amount of material does not allow formal naming although the cranidium of the Greenland form is clearly different from those of the other two species. From the type species, the Greenland material differs in having a relatively shorter and more anteriorly rounded glabella, wider preglabellar field and narrower anterior border (sag.). An incipient preglabellar ridge is almost in contact with the front of the glabella medially. T. ludlowensis has a glabella with constricted lateral outline which, in addition, is bluntly-rounded anteriorly. The pygidia of the three forms are similar.

Snajdr (1980, p. 176) separated Tetinia from Warburgella s.s. Reed, 1931 on the absence of a tropidium and on the structure of the anterior border of the cranidium. He there implied (p. 177) that $T$. ludlowensis was more closely related to Warburgella than was the type species. However, both of the Tetinia species lack a tropidium and both have a preglabellar ridge. This combination of characters separates these species and the Greenland form from Warburgella. They form a separate group worthy of generic rank although closely allied to the latter genus.

Acknowledgements. Merete Bjerreskov (University of Copenhagen) kindly identified the graptolites. R. M. Owens (National Museum of Wales) gave invaluable help. Thanks to B. S. Hansen and B. Larsen for technical assistance.

\section{References}

Alberti, G. K. B. 1967: Neue obersilurische sowie unter- und mitteldevonische Trilobiten aus Marokko, Deutschland und einigen anderen europäischen Gebieten. Senckenb. Leth. 48, 481-509.

Chlupáč, I. 1971: Some trilobites from the Silurian-Devonian boundary beds of Czechoslovakia. Palaeontology 14, 159-177.

Hurst, J. M. \& Surlyk, F. 1982: Stratigraphy of the Silurian turbidite sequence of North Greenland. Bull. Gronlands geol. Unders, 145, $121 \mathrm{pp}$.

Larsen, P.-H. \& Escher, J. C. 1985: The Silurian turbidite sequence of the Peary Land Group between Newman Bugt and Victoria Fjord, western North Greenland. Rapp. Grønlands geol. Unders. 125, $47-67$.

Owens, R. M. 1973: British Ordovician and Silurian Proetidae (Trilobita). Palaeontogr. Soc. (Monogr.), $98 \mathrm{pp}$.

Reed, F. R. C. 1931: The Lower Palaeozoic trilobites of Girvan. Supplement No. 2. Palaeontogr. Soc. (Monogr.), $30 \mathrm{pp}$.

Šnajdr, M. 1980: Bohemian, Silurian and Devonian Proetidae (Trilobita). Rozpr. Ústred. úst. geol. 45, $1-324$. 